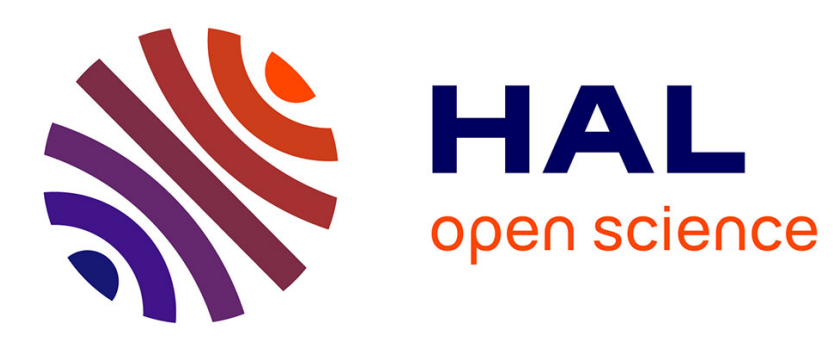

\title{
Structural Transformation of Immiscible Metals Induced by Mechanical Alloying
}

\author{
S. Wei, L. Yuan, W. Liu, K. Lu, Y. Yang
}

\section{To cite this version:}

S. Wei, L. Yuan, W. Liu, K. Lu, Y. Yang. Structural Transformation of Immiscible Metals Induced by Mechanical Alloying. Journal de Physique IV Proceedings, 1997, 7 (C2), pp.C2-1247-C2-1248. 10.1051/jp4:19972216 . jpa-00255289

\section{HAL Id: jpa-00255289 https://hal.science/jpa-00255289}

Submitted on 1 Jan 1997

HAL is a multi-disciplinary open access archive for the deposit and dissemination of scientific research documents, whether they are published or not. The documents may come from teaching and research institutions in France or abroad, or from public or private research centers.
L'archive ouverte pluridisciplinaire HAL, est destinée au dépôt et à la diffusion de documents scientifiques de niveau recherche, publiés ou non, émanant des établissements d'enseignement et de recherche français ou étrangers, des laboratoires publics ou privés. 


\title{
Structural Transformation of Immiscible Metals Induced by Mechanical Alloying
}

\author{
S. Wei, L. Yuan, W. Liu, K.Q. Lu* and Y. Yang** \\ Center for Fundamental Physics, and Hefei Synchrotron Radiation Laboratory, \\ University of Science \& Technology of China, Hefei 230026, P.R. China \\ * Institute of Physics, Chinese Academy of Science, Beijing, 100080, P.R. China \\ ** Institute of Solid State Physics, Chinese Academy of Science, Hefei 230031, P.R. China
}

\begin{abstract}
X-ray absorption fine structure(XAFS) is used to investigate the local structural change of $\mathrm{Fe}_{60} \mathrm{Cu}_{40}$ and $\mathrm{Fe}_{80} \mathrm{Cu}_{20}$ with the ball milling time. The XAFS results verify that the solid solution of mechanically alloyed Fe-Cu samples are inhomogeneous. We propose that the bcc to fec structural transformation of Fe small particles of $\mathrm{Fe} 60 \mathrm{Cu} 40$ ( $160 \mathrm{~h}$ ) is induced by interfacial $\mathrm{Cu}$ atoms dissolving in small $\mathrm{Fe}$ grain boundary during the mechanical alloying process.
\end{abstract}

\section{Introduction}

Recently, a new interest has arisen by the discovery that mechanical alloying(MA) can make some immiscible metals to form the metastable phase alloys. This phenomenon has been considered as that the solid solubility of immiscible binary metals can be greatly extended by MA. The mechanically alloyed $\mathrm{Fe}-\mathrm{Cu}$ binary metals is a representative alloy, its solid solubility and structure have been widely investigated by Shingu[1], Yavari[2], Crespo[3] and us[4] with $x$-ray diffraction(XRD), electron microscopy, and Mossbauer spectroscopy. The XRD patterns show the distinct peaks of fcc copper and bcc iron for initial $\mathrm{Fe}_{60} \mathrm{Cu}_{40}$ mixture. The bcc Fe peaks gradually decrease with the milling time, fully disappear after 160 hours milling and only fcc peaks remain. The bcc Fe peaks subsequently return after annealing at $773 \mathrm{~K}$. However, the local structure of $\mathrm{Fe}$ and $\mathrm{Cu}$ of mechanically alloyed $\mathrm{Fe}-\mathrm{Cu}$ samples has not been clear yet: whether or not the $\mathrm{Cu}$ atoms in the $\mathrm{Cu}$ lattice are homogeneously substituted by Fe atoms according to their chemical composition. In more recent studies, we found that $\mathrm{Fe}_{60} \mathrm{Cu}_{40}$ supersaturated solid solution forming from $\mathrm{MA}$ is inhomogeneous alloy by Mossbauer spectroscopy[4].

In this short report, XAFS has been performed to measure the local structures of $\mathrm{Fe}$ and $\mathrm{Cu}$ atomic neighbor environment of $\mathrm{Fe}_{60} \mathrm{Cu}_{40}$ and $\mathrm{Fe}_{80} \mathrm{Cu}_{20}$ samples at various ball milling time. Our aims are to study separately the structural change of $\mathrm{Fe}$ and $\mathrm{Cu}$ near neighbor coordination with the ball milling time, verify whether the $\mathrm{Fe}$ atoms are homogeneously dissolved into fcc metal $\mathrm{Cu}$ phase for $\mathrm{Fe}_{60} \mathrm{Cu}_{40}(160 \mathrm{~h})$ and the $\mathrm{Cu}$ atoms are dissolved into bcc $\mathrm{Fe}$ phase for $\mathrm{Fe}_{80} \mathrm{Cu}_{20}(160 \mathrm{~h})$.

\section{Experimental}

Crystalline iron and copper powders with particle sizes less than 200 mesh and purity higher than $99.9 \%$ were mixed to the desired composition. $10 \mathrm{~g}$ mixtures and $100 \mathrm{~g}$ tungsten carbide balls were sealed inside a cylindrical stainless steel vial filled with argon gas, and then MA was performed in a planetary ball with a rotation speed of about $210 \mathrm{r} / \mathrm{min}$. Fe-Cu mixtures milled for 10,40 and 160 hours, were represented as $\mathrm{Fe}-\mathrm{Cu}(10 \mathrm{~h}), \mathrm{Fe}-\mathrm{Cu}(40 \mathrm{~h}), \mathrm{Fe}-\mathrm{Cu}(160 \mathrm{~h})$, respectively.

The $\mathrm{Fe}$ and $\mathrm{Cu} \mathrm{K}$-edge $\mathrm{X}$-ray absorption spectra of mechanically alloyed $\mathrm{Fe}-\mathrm{Cu}$ samples were measured at the XAFS station of $4 \mathrm{WIB}$ beamline of Beijing Synchrotron Radiation Facility. The electron beam energy was $2.2 \mathrm{GeV}$ and maximumstored current is $50 \mathrm{~mA}$. Data were collected with a fixed exit monochromator using two flat $\mathrm{Si}(111)$ crystals. The energy solution was about $2 \sim 3 \mathrm{eV}$ by the $\mathrm{Cu}$ foil $3 \mathrm{~d}$ near edge feature. Data were collected in transmission mode using ion chambers with mixed $\mathrm{Ar} / \mathrm{N}_{2}$ fill gas at room temperature. The X-ray harmonics were minimized by detuning the two flat $\operatorname{Si}(111)$ crystal monochromator to about $70 \%$ of the maximum incident light intensity.

\section{Results and discussion}

The radial distribution functions(RDF) of $\mathrm{Fe}$ and $\mathrm{Cu}$ atoms of mechanically alloyed Fe-Cu binary metals are shown in Fig. 1. The RDF of bcc $\alpha-\mathrm{Fe}$ has three strong amplitude peaks $(\mathrm{R}=2.20 \AA, 3.66 \AA, 4.48 \AA)$ in the region of $1 \sim 6 \AA$. The magnitude intensity of the third peak of bcc $\alpha-\mathrm{Fe}$ is very stronger, many times larger than the corresponding third peak of fcc metal $\mathrm{Cu}$. We can then recognize the local neighbor structure of $\mathrm{Fe}$ or $\mathrm{Cu}$ for mechanically alloyed $\mathrm{Fe}-\mathrm{Cu}$ samples with this character. It can be observed in Fig. 1 that the magnitude intensity of the first peak of $\mathrm{Fe}_{60} \mathrm{Cu}_{40}$ sample gradually decreases with the milling time. After 160 hours ball milling, The magnitude intensity of main peak drops about one third. The third peak $(R=4.48 \AA)$ disappears for the $\mathrm{Fe}_{60} \mathrm{Cu}_{40}(160 \mathrm{~h})$, its feature of RDF is completely different from that of bcc $\alpha-\mathrm{Fe}$, but is similar to that of fcc 

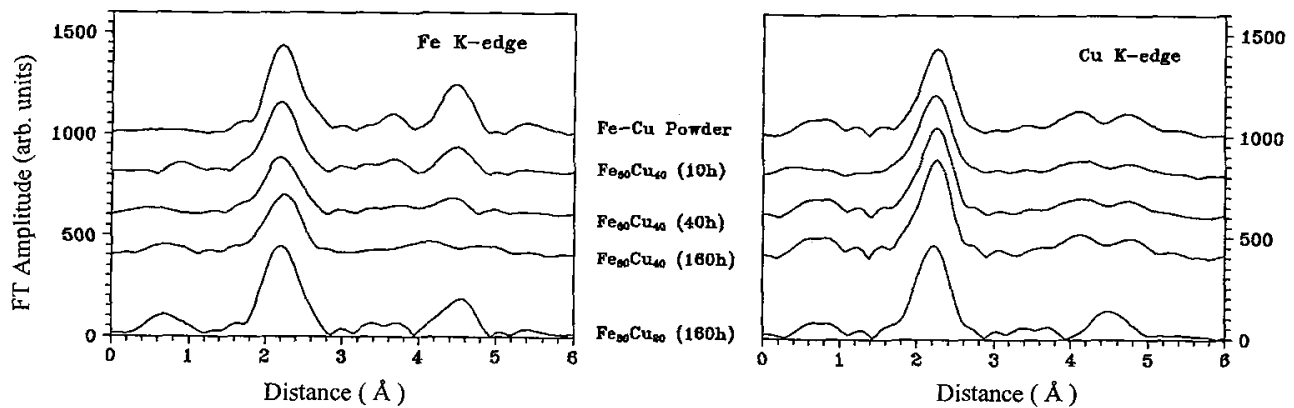

Fig.1 The $\mathrm{RDF}$ of $\mathrm{Fe}$ and $\mathrm{Cu}$ atoms for mechanically alloyed $\mathrm{Fe}-\mathrm{Cu}$ samples

metal $\mathrm{Cu}$ (three stronger amplitude peaks of fcc metal $\mathrm{Cu}$ are at $2.26 \AA, 4.12 \AA$ and $4.74 \AA$ ). This result confirms that the $\mathrm{MA}$ can change the neighbor environment of $\mathrm{Fe}$ atoms of $\mathrm{Fe}_{60} \mathrm{Cu}_{40}$ from bcc structure to fcc structure. The $\mathrm{Fe}$ atoms of $\mathrm{Fe}_{80} \mathrm{Cu}_{20}$ exist still in the form of bcc structure in spite of 160 hour milling. Moreover, the magnitude intensity of main peak is the same as that of its initial $\mathrm{Fe}_{80} \mathrm{Cu}_{20}$ powder mixture. We noted an interesting XAFS results, the RDF of $\mathrm{Cu}$ in $\mathrm{Fe}_{80} \mathrm{Cu}_{20}(160 \mathrm{~h})$ appears the third stronger peak at $4.48 \AA$, which is similar to that of bcc $\alpha$-Fe. It suggests that the Cu neighbor coordination environment of $\mathrm{Fe}_{80} \mathrm{Cu}_{20}$ is changed from fcc structure to bcc structure after 160 hour milling.

Although the $\mathrm{Fe}_{60} \mathrm{Cu}_{40}$ was milled 160 hours, the magnitude intensity of the main peak of $\mathrm{Cu}$ appears no evident change. It means that the $\mathrm{Cu}$ local neighbor structure of $\mathrm{Fe}-\mathrm{Cu}(160 \mathrm{~h})$ is the same as that of its initial $\mathrm{Fe}-\mathrm{Cu}$ mixture. MA does not increase the disorder degree of $\mathrm{Cu}$ neighbor coordination of $\mathrm{Fe}_{60} \mathrm{Cu}_{40}$ samples, even if the disorder degree of the other element $\mathrm{Fe}$ increases with the milling time. Therefore, it is impossible that much amount metal $\mathrm{Fe}$ is dissolved into $\mathrm{Cu}$ phase. Table $\mathrm{I}$ lists the fitting results for the $\mathrm{Fe}_{60} \mathrm{Cu}_{40}(160 \mathrm{~h})$ and $\mathrm{Fe}_{80} \mathrm{Cu}_{20}(160 \mathrm{~h})$. The structural parameters show that $\mathrm{Fe}$ atoms or $\mathrm{Cu}$ atoms are coordinated by both of $\mathrm{Fe}$ and $\mathrm{Cu}$ atoms in the nearest neighbor shell. The $\mathrm{Fe}$ atoms are mainly surrounded by $\mathrm{Fe}$ atoms and the $\mathrm{Cu}$ atoms are still tending to coordinated by $\mathrm{Cu}$ atoms for $\mathrm{Fe}_{60} \mathrm{Cu}_{40}(160 \mathrm{~h})$, the ratio of $\mathrm{Fe}$ coordination number to $\mathrm{Cu}$ coordination number in Fe first coordination shell greatly deviates from its chemical composition. XAFS results indicate that $\mathrm{Fe}$ is rich in some region and $\mathrm{Cu}$ is rich in other region for these $\mathrm{MA} \mathrm{Fe}-\mathrm{Cu}$ samples. This conclusion is supported by the results of Mossbauer spectroscopy[4] and high-resolution transmission electron microscopy[5]. XAFS results further verified that $\mathrm{Cu}$ atoms of fcc $\mathrm{Cu}$ lattice in $\mathrm{Fe}_{60} \mathrm{Cu}_{40}(160 \mathrm{~h})$ are not homogeneously substituted by Fe atoms after 160 hour milling.

Table 1. The structural parameters of the first shell for $\mathrm{Fe}-\mathrm{Cu}$ samples fitting with $\mathrm{Fe}$ and $\mathrm{Cu} \mathrm{K}$-edge XAFS spectra

\begin{tabular}{|c|c|c|c|c|c|c|c|c|c|c|c|c|}
\hline sample & K-edge & bond type & $\mathbf{R}(\AA)$ & $\sigma(\AA)$ & $\mathrm{N}$ & $\Delta \mathrm{E}_{0}$ & K-edge & bond type & $\mathrm{R}(\bar{\AA}$ & $\sigma(\AA)$ & $\bar{N}$ & $\overline{\Delta \mathrm{E}_{0}}$ \\
\hline $\mathrm{Fe}_{60} \mathrm{Cu}_{40}(160 \mathrm{~h})$ & $\mathrm{Fe}$ & $\mathrm{Fe}-\mathrm{Fe}$ & 2.56 & 0.094 & 8.2 & 1.0 & $\mathrm{Cu}$ & $\mathrm{Cu}-\mathrm{Cu}$ & 2.56 & 0.089 & 6.6 & 4.0 \\
\hline & & $\mathrm{Fe}-\mathrm{Cu}$ & 2.56 & 0.089 & 3.3 & -3.7 & & $\mathrm{Cu}$ & 2.5 & 0.087 & 5.2 & -1.1 \\
\hline $\mathrm{Fe}_{80} \mathrm{Cu}_{20}(160 \mathrm{~h})$ & $\mathrm{Fe}$ & $\begin{array}{l}\mathrm{Fe}-\mathrm{Fe} \\
\mathrm{Fe}-\mathrm{Cu}\end{array}$ & $\begin{array}{c}2.49 \\
2.50\end{array}$ & $\begin{array}{c}0.079 \\
0.080\end{array}$ & $\begin{array}{c}7.0 \\
1.0\end{array}$ & $\begin{array}{c}2.0 \\
-2.7\end{array}$ & $\mathrm{Cu}$ & $\begin{array}{l}\mathrm{Cu}-\mathrm{Cu} \\
\mathrm{Cu}-\mathrm{Fe}\end{array}$ & $\begin{array}{l}2.50 \\
2.50\end{array}$ & $\begin{array}{c}0.079 \\
0.080\end{array}$ & $\begin{array}{l}5.5 \\
3.6\end{array}$ & $\begin{array}{l}2.0 \\
2.5\end{array}$ \\
\hline
\end{tabular}

During the milling process to make $\mathrm{Fe}-\mathrm{Cu}$ powder mixture down into small particles, the interdiffusions of $\mathrm{Fe}$ and $\mathrm{Cu}$ are simulanteously produced in the region of $\mathrm{Fe}$ grain boundary coherent with $\mathrm{Cu}$ grain by $\mathrm{MA}$. We observed that the mechanically alloyed Fe-Cu samples are nanometer particles with transmission electron microscope[6]. Moreover, the higher $\mathrm{Cu}$ concentration is more effective to make the $\mathrm{Fe}-\mathrm{Cu}$ powder mixture the small size particles. For $\mathrm{Fe}_{60} \mathrm{Cu}_{40}(160 \mathrm{~h})$, we consider that only little amount of $\mathrm{Cu}$ atoms can diffuse into the core of $\mathrm{Fe}$ grain which corresponds to a $\mathrm{Fe}$-rich region, deducing from the structural parameters in table 1 . The bce structural $\mathrm{Fe}$ grain is unstable while $\mathrm{Cu}$ atoms reach some concentration in the interfacial region and $\mathrm{Fe}$ grains are broken down to very small sizes. Interfacial $\mathrm{Cu}$ atoms drive phase transition from bcc $\alpha-\mathrm{Fe}$ to metastable fcc Fe phase. For $\mathrm{Fe}_{80} \mathrm{Cu}_{20}(160 \mathrm{~h})$, the $\mathrm{Cu}$ atomic concentration is lower, so that $\mathrm{Fe}$ particles are not broken down to small size. Fe particles keep the bcc $\alpha$-Fe structure. On contrary to $\mathrm{Fe}_{60} \mathrm{Cu}_{40}(160 \mathrm{~h})$, fcc $\mathrm{Cu}$ phase is transformed to bcc phase, inducing by bcc $\alpha-F e$ phase.

\section{Acknowledgments}

We would like to thank BSRF for giving us the beam time for XAFS measurement. This work was supported by National Natural Science Foundation of China and Young Scholar Science Foundation of USTC.

\section{References}

[1]. Uenishi K., Kobayashi F., Nash S., Hatano H, Ishihara K.N. and Shingu P.H., Z. Metallkd. 83, 132(1992).

[2]. Yavari A.R., Desre P.J., and Benameur T., Phys. Rev. Lett. 68, 2235(1992).

[3]. Crospo P., Hernando A., Drbohlav D., Escorial A.G., Barandiaran J.M. and Orue I., Phys. Rev.B48, 7134(1993); B49, 13227(1994).

[4]. Wei S.Q., Yin S.L., Liu W.H., Yang Y.Z., Dong Y.D. and Hu T.D., J. Phys. Sinica, 43, 1630(1994); Phys. Rev. B52, 1120(1995).

[5]. Huang J.Y., Wu Y.K., He A.Q., Hu K.Y., and Meng Q.M., J. Chinese Electron Microscopy Society, 13, 26(1994).

[6]. Wei S.Q., Yuan L.F., Liu W.H., and Yang Y.Z., (submitted to Phys. Rev. Lett.). 